\title{
Massive Necrosis of the Brain in Rabies
}

\author{
C.L. Dolman and K.M. Charlton
}

\begin{abstract}
A young man developed virologically proved hydrophobic rabies three months after being scratched on the cheek by a bat in Northern Alberta. He became comatose after 8 days and died 5 weeks after vigorous therapy with immune globulin, interferon and Vidarabine, and excellent maintenance of oxygenation. Electroencephalographic deterioration was gradual. At postmortem examination, the brain showed widespread loss of nerve cells, mild diffuse inflammatory changes and no Negri bodies. The lesions of massive laminar necrosis of the cerebral cortex, total loss of Purkinje cells with preservation of the granule cell layer, and severe softening of the amygdala are attributed to direct viral action rather than to anoxia or brain swelling with respirator brain.
\end{abstract}

\begin{abstract}
RÉSUMÉ: Nécrose cérébrale massive due à la rage Dans la région septentrionale de l'Alberta, un jeune homme a développé la rage trois mois après avoir été égratigné sur la joue par une chauve-souris. Huit jours après le début de la maladie, il est devenu comateux et il décédait en 5 semaines, malgré une thérapie intensive au moyen d'immunoglobuline, d'interféron et de Vidarabine et d'une excellente oxygénation de soutien. La détérioration de l'enregistrement électroencéphalographique fut graduelle. À l'autopsie, le cerveau présentait une perte étendue de neurones et des modifications inflammatoires légères, mais diffuses sans corps de Négri. Nous croyons que la nécrose laminaire massive du cortex cérébral, la perte de toutes les cellules de Purkinje avec préservation des cellules granulaires du cervelet et la ramolissement sévère des noyaux amygdaliens sont directement attribuables à l'action du virus et non à l'anoxie ou à l'oedème cérébral qu'on retrouve dans le syndrome du patient maintenu sous respirateur.
\end{abstract}

Can. J. Neurol. Sci. 1987; 14:162-165

In Canada, rabies is enzootic in foxes, skunks and insectivorous bats. The principal wildlife vectors in affected areas are as follows: Manitoba and Saskatchewan, skunks; Ontario and Quebec, red fox and skunk, Northwest Territories, arctic fox. Rabies has been diagnosed in bats in 8 provinces and occasional cases of bat-transmitted rabies have occurred in both man and other animals.' Human cases, however, are quite rare. In 1970 , two weeks after a bat flew into his face, a 15 year old boy in Saskatchewan died of rabies, as proven by isolation of the virus from postmortem brain and spinal cord tissue. ${ }^{2}$ In 1978, a 63 year old man in Nova Scotia succumbed to rabies 1 year after being bitten by a bat on the left hand. ${ }^{1,3}$ In neither patient was the disease diagnosed before death and the bats were not examined. In other parts of the world, animals may overcome the infection and perhaps form an asymptomatic reservoir of carriers, ${ }^{4.5}$ but this has not been demonstrated in Canada. In man the disease, once it develops clinically, is almost invariably fatal. Occasionally, patients do survive, ${ }^{4.6}$ and this, coupled with the fact that even after several weeks of survival, inflammatory changes may be mild, is considered a reason for continued life support. The case to be presented here, on the other hand, showed massive destruction of the brain.

\section{CASE RePort}

In July 1985, while working in a youth camp in Northern Alberta, Canada, a 25 year old man sustained a superficial claw injury on the left cheek from a brown bat which fell on him from the top of the tent. He pulled the bat off and threw it outside. The animal was gone the next morning. The only treatment was local antiseptic. Three months later, on October 24th, he fell ill with a "kink" in the right side of the neck, followed by chest discomfort and general malaise. Over the next 2-3 days, he noted a sticky sensation in his throat. By October 30 , he had a high fever and the mere sight of water brought on dry heaving. The patient was admitted to hospital. His temperature was $40^{\circ} \mathrm{C}$. He had severe but painless muscle spasms, most marked in the neck and pharynx. Tone was diffusely increased and he had priapism. On November 1, he was still alert, but had developed incoordination and moderate rightsided weakness. An Ommaya reservoir was inserted. He became comatose on November 4th. A tracheostomy was done and he was ventilated artificially; oxygenation was excellent throughout his illness. Rabies immune globulin was administered in 1 and $5 \mathrm{mldoses}$, intramuscularly from October 31 , and into the lateral ventricle of the brain by Ommaya reservoir, from November 1 daily to November 26 . Ten mega units of interferon were given daily intramuscularly from October 31 and intraventricularly from November 1 to November 20 . Intravenous Vidarabine was given, 350 mgm over 24 hours, from November 1 to 5 , then $700 \mathrm{mgm}$ until November 11 . During the placement of the reservoir, a brain biopsy was taken. This appeared histologically normal (Figure 1a), but rabies fluorescent antibody stains ${ }^{7}$ were positive and virus was 


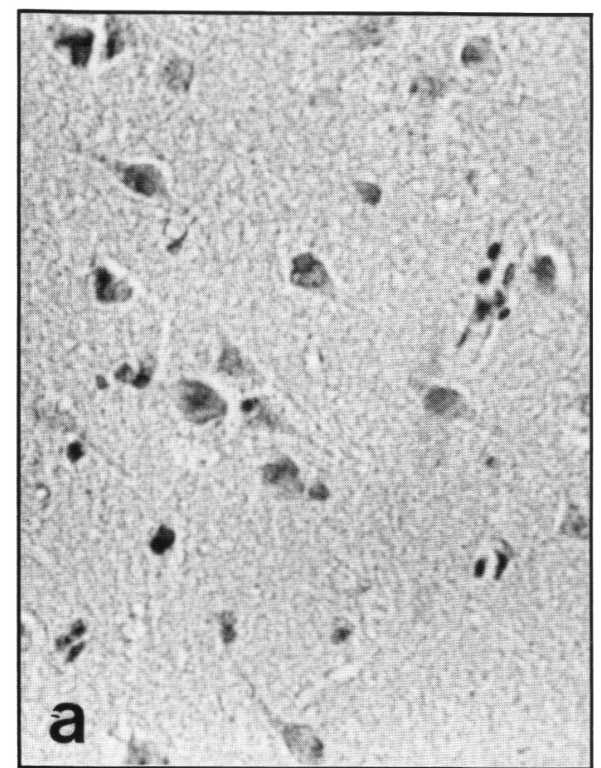

Figure la - Cortical biopsy. Nerve cells are intact and there are neither Negri bodies nor any inflammation.

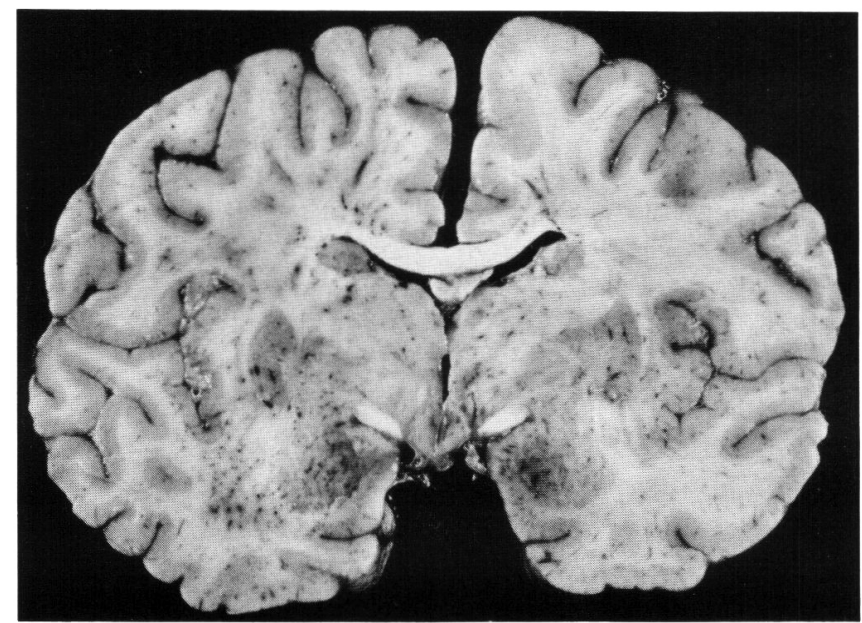

Figure 2 - Coronal section of brain at level of amygdaloid nucleus. The brain is swollen and congested, especially in the region of the amygdala.

isolated in neuroblastoma cell tissue culture ${ }^{8}$ The antigenic profile was determined with rabies antinucleocapsid monoclonal antibodies supplied by Dr. T. Wiktor, Wistar Institute, Philadelphia. The profile was identical to that of virus isolated from several bat species in western Canada (bat group 2). ${ }^{8,9}$ The patient remained comatose, the spasms ceased and he became completely flaccid. Life support was discontinued on November 26 and he died.

An electroencephalogram on October 31 was considered within normal limits. On November 5 and 7 , when the patient was already comatose, it showed persistent electrical activity with diffuse abnormal low voltage waves, indicating widespread and severe disturbances in cerebral function, both cortical and subcortical. On November 13, semi-rhythmic high amplitude, posteriorly dominant multiphasic spike or slow wave activity was recorded, and this was considered to be changed significantly from the reading on November 7 . By November 18, very little electrical activity was present. By November 25 , the tracing was considered to be isoelectric.

On November 4 , rabies neutralizing antibody titer (performed by the National Rabies Reference Laboratory in Toronto) in serum was 1:1. In CSF it read on November 4: less than 1:2, on November 6: 1:64, on November 7 , both pre and post interferon: 1:16, on November $8: 1: 4$, on the 14th: more than 1:256, and on the 16th and 19th: 1:64.

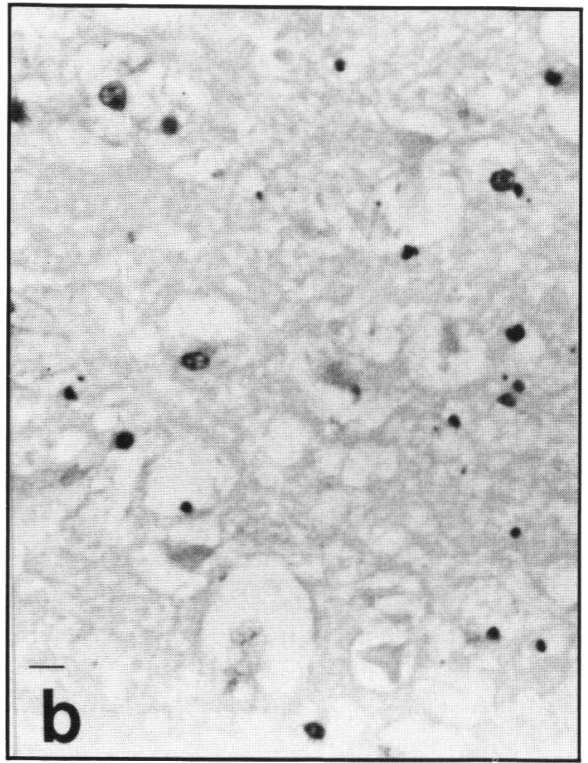

Figure $l b$ - Diffuse necrosis of cerebral cortex at autopsy. Nerve cells are ischemic shadows among kariorrhectic debris. Both figures Hematorylin and eosin, $x 750$

At postmortem examination, the lungs were congested, the heart and other internal organs were normal. The pituitary gland contained small foci of recent necrosis. The brain was moderately swollen and congested, particularly in the region of the amygdala (Figure 2). Histologically the most prominent feature was extensive, widespread loss of nerve cells coupled with inflammation. The cerebral cortex throughout showed total recent necrosis. The ghosts of nerve cells could still be discerned and there was much karyorrhexic debris (Fig. Ib). Extremely few nerve cells had survived. No Negri bodies were seen. Throughout there was a mild inflammatory reaction of perivascular cuffing by lymphocytes, a few plasma cells, and monocytic cells, and a similar reaction in the leptomeninges. The endothelium of the capillaries was markedly swollen. In the basal ganglia, nerve cells had almost disappeared, but there was not the massive necrosis as in the cortex. Inflammation was similar to that in the cortex. In the thalamus, small groups of nerve cells had survived, but the bulk of the tissue was devastated. In the hippocampus, a few neurons persisted in the dentate gyrus; otherwise the tissue was softened and filled with macrophages, and the same was true of the amygdaloid nucleus. The midbrain, pons and medulla had nearly completely lost their neurons and vessels were cuffed by mononuclear cells. The pons contained small astrocytic scars. In the cerebellum all Purkinje cells and neurons of the dentate and other central nuclei had disappeared. Most but not all granule cells had survived. The white matter of the cerebellum was inflamed, showing a diffuse infiltration by lymphocytes and both diffuse and focal accumulations of monocytic cells (Figure 3). The upper cervical spinal cord had lost its neurons and was inflamed (Figure 4). Inflammation extended also into nerve roots of the cranial and spinal nerves. Some astrocytosis was present, but was not marked.

Samples of cerebral and cerebellar cortex, hippocampus and medulla, submitted to the Animal Diseases Research Institute, Agriculture Canada. Nepean, Ontario, were positive with the rabies fluorescent antibody test (Figure 5). Virus could not be grown from these specimens in tissue culture. Other organs, including heart and lung, were not tested by the fluorescent antibody test and live virus was not isolated from them.

\section{Discussion}

Human rabies may show variable degrees of inflammation, from negligible to severe. ${ }^{10.11,12}$ The brunt of the damage usually falls on the brainstem and spinal cord. More widespread destruction in some subjects with prolonged survival ${ }^{13}$ has been attributed to cerebral edema and hypoxia. Rubin and his 
collaborators ${ }^{14}$ reported a patient who survived for 64 days and showed laminar cortical necrosis and total loss of Purkinje cells, lesions identical to those found by us. Since their patient had suffered several cardio-respiratory arrests and eventually died as a result of respiratory failure, the lesions were thought to be caused by anoxia. But the complete softening of the hippocampal formation and amygdala, which we found, the loss of nerve cells in the brainstem and spinal cord and of Purkinje cells and neurons of the dentate nucleus in the cerebellum, with preservation of the molecular and granule cell layers, matches the known topographical predilection of the virus, and is not typical of anoxic damage. The recent massive necrosis of the neocortex could be due to anoxia. However, ventilation and oxygenation were well maintained in our patient throughout. The deterioration in the electroencephalograms was gradual and consistent with a progressive diffuse encephalopathy due to inflammation rather than to isolated anoxic events. There was no evidence of heart failure, and the myocardium was histologically normal. Virus was cultured from the cortical biopsy and mononuclear cuffing at autopsy indicated the presence of inflammation. The brain was only moderately edematous at necropsy and did not show the total autolysis of a respirator brain.

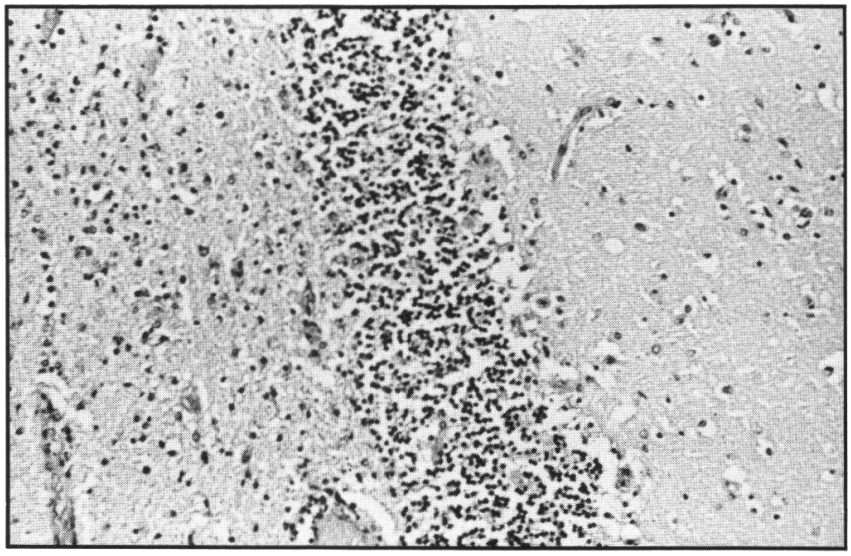

Figure 3 - Cerebellar cortex. Purkinje cells are absent between the intact granule cell layer in the center and the molecular layer to the right. The white matter at the left is more cellular than normal, being infiltrated by inflammatory cells. Hematoxylin and eosin, $x 300$

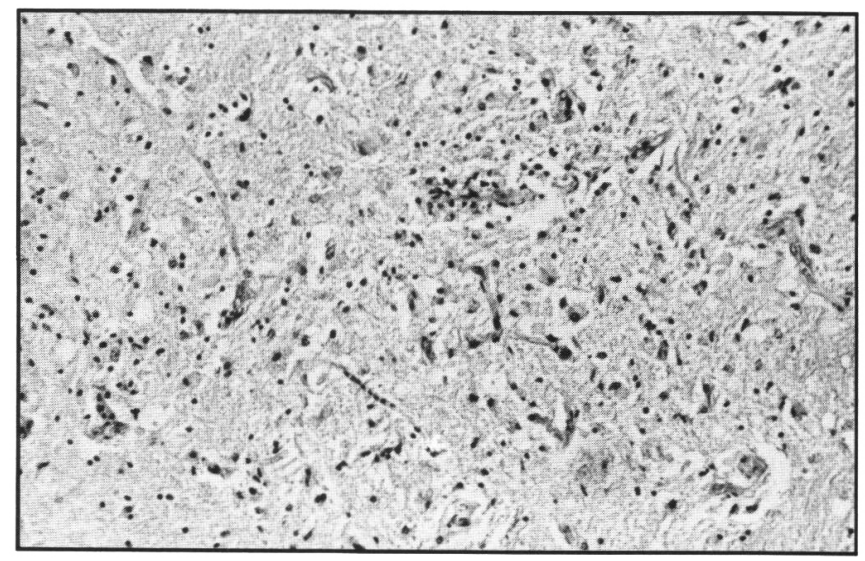

Figure 4 - The ventral horn of the spinal cord has lost all its nerve cells. Hematoxylin and eosin, $x 300$
Since the patient had received large doses of Vidarabine, toxic effects of the drug were suspected. This is unlikely, since the only reported effect of such toxicity has been widespread chromatolysis. ${ }^{15,16}$ Rabies virus may persist in the brain for considerable time, as indicated by the presence of Negri bodies in some patients who have been kept alive for several weeks on the respirator. The massive necrosis seen in our case most likely represents the direct lytic effect of the virus or perhaps interaction of virus and antiserum and is one end of the spectrum of pathological changes which may occur in rabies.

The cerebrospinal fluid antibody titers in our patient rose very little, despite constant infusions of immune globulin. The boy reported by Hattwick et al, ${ }^{6}$ who recovered from a presumed bout of rabies, had an enormous increase in antibodies. Kent and Finegold ${ }^{17}$ suggest that anti-rabies serum may depress the development of antibodies. A marked or absent response may have a bearing on the damage done by the virus.

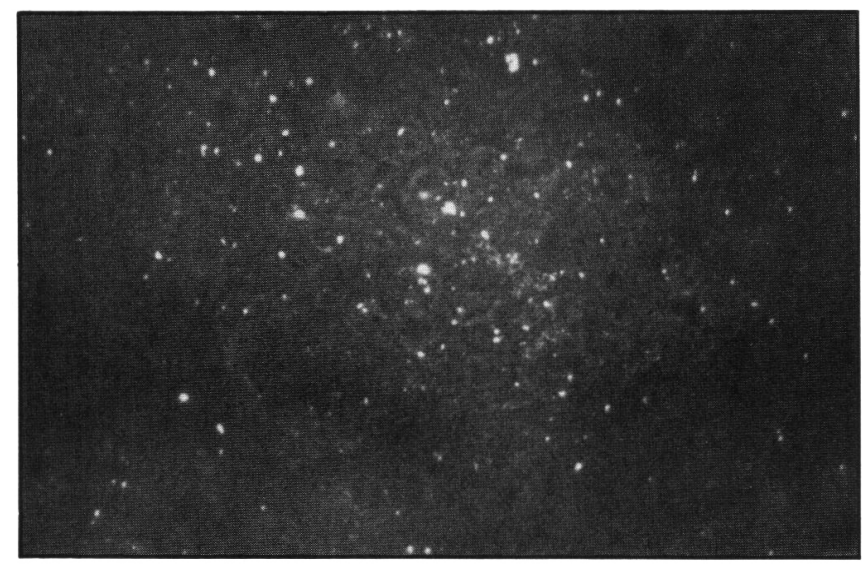

Figure 5 - Cerebral cortex stains positively with the rabies fluorescent antibody test. $\times 300$

\section{REFERENCES}

1. Canada diseases weekly report. A suspected case of human rabies - Nova Scotia. 1978; 4-13: 49-51.

2. Dempster G, Grodums EI, Bayatpour M, et al. A human case of unsuspected rabies in Saskatchewan diagnosed by virus isolation. Can J Pub Health 1972; 63: 215-218.

3. King DB, Sangalang VE, Manuel R, et al. A suspected case of human rabies, Nova Scotia. Canada Dis Weekly Rep 1978;4-13: 49-50.

4. Macdonald DW. Rabies and Wildlife. A biological perspective. Oxford University Press, Oxford, 1980; 12.

5. Bell JF. Latency and abortive rabies. In: The Natural History of Rabies, Baer GM, ed., Academic Press, New York, San Francisco, London, 1976; 331-355.

6. Hattwick MA, Weis TT, Stechschulte J, et al. Recovery from rabies. A case report. Ann Int Med 1972; 76: 931-942.

7. Dean DJ, Abelseth. The fluorescent antibody test. In: Laboratory Techniques in Rabies, Kaplan MM, Koprowsky H, ed., 3rd ed., WHO, Geneva, 1973; 73-83.

8. Webster WA, Casey GA, Charlton KM, et al. A case of human rabies in Western Canada. Can J Publ Health - in press.

9. Webster WA, Casey GA, Charlton KM. Major antigenic groups of rabies virus in Canada determined by anti-nucleocapsid monoclonal antibodies. Comp Immun Microbiol Infect Dis 1986; 9: 59-69.

10. Dupont JR, Earle KM. Human rabies encephalitis. A study of forty-nine fatal cases with a review of the literature. Neurology 1965; 15: 1023-1034 
11. Perl DP. The pathology of rabies in the central nervous system. $I n$ : The Natural History of Rabies, Baer GM, ed., Academic Press, New York, San Francisco, London, 1976; 236-272.

12. Warrell DA, Davidson NMCD, Pope HM, et al. Pathophysiologic studies in human rabies. Am J Med 1976; 60: 180-190.

13. Atanasiu P, Garnet A. Rabies. In: Handbook of Clinical Neurology, Vinken PJ, Bruyn GW, ed. Elesvier North-Holland Biomedical Press, Amsterdam, New York, Oxford, 1978; 34: 235-274.

14. Rubin RH, Sullivan L, Summers R, Gregg MG, Sikes RK. A case of human rabies in Kansas: Epidemiologic, clinical and laboratory considerations. J Inf Dis 1970; 122: 318-332.
15. Marker S, Howard RJ, Groth KE, et al. A trial of vidarabine for cytomegalovirus in renal transplant patients. Arch Int Med 1980; 140: 1441-1444.

16. Van Etta L, Brown J, Mastri A, et al. Fatal vidarabine toxicity in a patient with normal renal function. JAMA 1981; 246: 1703-1705.

17. Kent JR, Finegold SM. Human rabies transmitted by the bite of a bat. With comments on the duck-embryo vaccine. New Eng J Med 1960; 263: 1058-1065. 